\title{
Augusto Meyer: o discurso poético na crítica literária
}

Nelson Ricardo Guedes dos Reis I Doutor em Literatura Comparada pela UFMG

Resumo: Este ensaio pretende demonstrar a presença de um discurso "poético" na obra crítica de Augusto Meyer. Com este objetivo fizemos um levantamento de seu percurso literário e nos dedicamos à análise de trechos de alguns de seus ensaios da maturidade.

Palavras-chave: crítica, poética, Augusto Meyer.

\section{A formação do crítico}

Caberia num livro? Imagino-o transformado no livro de si mesmo: volume fino, alongado, de elegante encadernação, tipos escolhidos, vinhetas desenhadas por um diabinho renascentista que, aqui e ali, pusesse um toque de Bilú no contorno das figuras. Livro que fosse a síntese de uma biblioteca sem obras indigestas, cultura presente como atmosfera ou água de beber. (Carlos Drummond de Andrade. Trecho do artigo "De Meyer a Bilú", publicado no Jornal do Brasil em 16/07/1970.)

A obra crítica de Augusto Meyer se divide em duas frentes: a compreensão do fazer literário, ou seja, a adoção de uma "postura" analítica e interpretativa perante a obra literária, e a produção da linguagem; no caso de seus 
ensaios críticos, uma linguagem que interage e se confunde com o próprio texto literário, não na essência ficcional ou estilística deste, mimetizando-o, mas pela adoção de uma "atitude" literária (literariedade) perante a linguagem. Segundo Eduardo Portella, Meyer é "um produtor de linguagem, um inventor. Um inventor que se serve da palavra para inventar. E é também um grande entendedor do fazer literário, alguém que reflete o tempo todo, que pensa cada palavra que escreve". Acreditamos que quando Portella diz que Meyer é "um inventor que se serve da palavra para inventar", ele está falando da maneira pela qual o texto é "vazado" em linguagem propriamente literária.

É difícil compreender a "atitude" crítica de Meyer sem conhecermos e entendermos, primeiro, seus percursos literário e crítico, que praticamente caminharam juntos durante toda sua vida. Augusto Meyer nasce em 24 de janeiro de 1902, na cidade de Porto Alegre, no Rio Grande do Sul. Dezessete anos depois, em 1919, na revista A máscara, publica seu primeiro conto, chamado "O pastelão". Em 1922 temos as primeiras referências acerca de sua produção crítica: os ensaios "Omar Khayýam" e "Alphonsus de Guimarães", publicados no jornal Echo do Sul, da cidade de Rio Grande. A partir desse ano Meyer passa a publicar, esporadicamente, textos críticos no jornal $O$ exemplo. Mas é apenas a partir de 1925 que seus ensaios passam a manter regularidade e aparecer em grandes jornais de Porto Alegre, como Correio do Povo e Diário de Notícias. É interessante notar, entretanto, que a produção de Augusto Meyer publicada nesses três jornais é constituída predominantemente de poemas, crônicas e contos, possuindo apenas 53 textos classificados como críticos pela pesquisadora de sua obra, a professora Tânia Franco Carvalhal, 'num universo de 329 textos. Entretanto, muitos dos "textos" que foram publicados como crônicas são ensaios críticos, já indicando, assim, sua tendência de subverter os limites entre os gêneros.

As primeiras obras publicadas por Augusto Meyer são livros de poemas, dentre eles Coração Verde, de 1926; Giraluz, de 1928; Duas Orações, de 1928 e Poemas de Bilu, de 1929. Este último fez com que Mário de Andrade incluísse Meyer entre "os maiores líricos do Brasil contemporâneo", 3 ao lado de Drummond e Bandeira. Só em 1935 Meyer lança seu primeiro livro de crítica

1. PORTELlA. Reencontrando Augusto Meyer, p. 2.

2. CARVAlHAL. O crítico à sombra da estante, p. 135-147.

3. ANDRADE, apud CARVALHAL. O crítico à sombra da estante, p. 7. 
literária: Machado de Assis. A partir desse livro, o crítico que sempre esteve presente na obra de Augusto Meyer, mas que exercia um posto de coadjuvante em relação ao poeta, assume as rédeas da produção literária de Meyer, que só volta à poesia vinte anos depois, em Últimos poemas: a despedida literária do poeta Augusto Meyer. Do poeta fazedor de poemas, que fique claro, porque o poeta da palavra justa, do lirismo subjacente ao texto crítico, esse nunca deixou de acompanhar o autor.

Para Tânia Franco Carvalhal essa transição ocorre um pouco antes, em 1931, com a publicação de Literatura e poesia:

Em 1931, publica Literatura e Poesia, em que dá livre expansão a uma prosa que mal disfarça o poético, misturando reminiscências sentimentais e literárias. [...] Cala-se então o poeta e surge o crítico. A transição é profeticamente anunciada por Moysés Vellinho: 'É possível que o crítico tenha absorvido o poeta para que o poeta sobrevivesse no crítico. ${ }^{4}$

O que fica claro, entretanto, se analisarmos cuidadosamente sua biografia, em conjunto com sua bibliografia, é que na década de 1920, quando se inicia sua atividade literária, o poeta, o cronista e o contista prevalecem sobre o crítico, tanto na produção publicada em jornais, quanto nos livros publicados (todos de poesia). Em 1931, com a publicação do já citado Literatura e poesia - cujo título nos deixa entrever os novos rumos tomados pelo autor -, há uma mudança clara de caminho, em que o crítico passa a assumir uma posição de destaque em relação ao poeta, porém sem nunca eliminá-lo totalmente, mas convivendo este à sombra daquele. Segundo Carlos Dante de Moraes:

Não tenhamos dúvida, Literatura e Poesia é uma despedida. É a festa de um espírito que não mais voltará aos caminhos líricos. Há nele, por isso, o ardor, a policromia, a fantasia solta de um baile de máscaras. O poeta chegou a um novo impasse, dessa vez definitivo. O seu drama já não tem solução. Agora são as palavras que o traem. Como poderão elas exprimir o 'novo' se estão demasiado comprometidas de associações lógicas e literárias? Por isso, antes de quebrar o instrumento poético, diverte-se como o mascarado barulhento que amanhã deverá entrar na regra e na vida prosaica.

4. CARVAlHal. O crítico à sombra da estante, p. 2.

5. MORAES. Realidade e ficção, p. 60. 
Não vemos, porém, no trabalho crítico de Meyer, uma "quebra" do "instrumento poético", como sugere Dante de Moraes; muito antes pelo contrário, percebemos no trabalho crítico desse autor a presença do "poético", que se encontra subjacente em grande parte de seus ensaios críticos e teóricos, como tentaremos demonstrar nas próximas páginas.

\section{À sombra da estante}

Dizer que um crítico literário vive à sombra da estante, seja a sua ou a de qualquer biblioteca que o abasteça de livros para exercer sua função, que quase sempre é também uma forma de paixão, é dizer mais ou menos o óbvio. Contudo, há críticos que mantiveram com suas "estantes", ou seja, com os livros, uma relação antes e prioritariamente de leitor, para só depois deixar falar o crítico. Pois nem todos os críticos mantiveram com o livro, com a literatura em si, uma relação de respeito e intimidade, onde o leitor ingênuo que existe em todo crítico abre passagem, rompe as primeiras páginas, para só aí o leitor-crítico surgir (e não o crítico-leitor). Esse movimento é essencial para entendermos a escritura que surge no texto de Augusto Meyer.

Meyer lança seu primeiro livro de crítica, dedicado a mais de um autor (Machado de Assis, de 1935, só possuía ensaios dedicados ao autor de Dom Casmurro), em 1947, composto de ensaios dispersos em vários jornais nos últimos vinte anos: À sombra da estante. Já no texto que abre o livro, Meyer deixa claro seu "projeto" crítico e, principalmente, sua postura crítica. O ensaio chama-se "Do leitor" e inicia-se assim:

Ler um livro é desinteressar-se a gente desse mundo comum e objetivo para viver noutro mundo. A janela iluminada noite adentro isola o leitor da realidade da rua, que é o sumidouro da vida subjetiva. Árvores ramalham. De vez em quando passam passos. Lá no alto estrelas teimosas namoram inutilmente a janela iluminada. O homem, prisioneiro do círculo claro da lâmpada, apenas ligado a este mundo pela fatalidade vegetativa do seu corpo, está suspenso no ponto ideal de uma outra dimensão, além do tempo e do espaço. No tapete voador só há lugar para dois passageiros: leitor e autor. ${ }^{6}$

6. meyer, Textos críticos, p. 3. 
Meyer, nessa introdução de seu ensaio, nos desnuda aquele leitor que viaja nas páginas de um livro, que dá asas à fantasia e à imaginação. ${ }^{7}$ Aquele leitor que ele mesmo chama de ingênuo:

O leitor ingênuo é simplesmente ator. [...] procura o reflexo dos seus sentimentos imediatos, identificando-se logo com o protagonista ou herói do romance. Isto, aliás, se dá mais ou menos com qualquer leitor, diante de qualquer livro; de modo geral, nós nos lemos através dos livros.

Mas esse leitor "ingênuo", se tomar de fato gosto pela leitura, tende a perder, com o passar do tempo, essa ingenuidade, essa "faculdade quixotesca de se encarnar nos heróis romanceados [...] O ator transforma-se em espectador. Removida a atenção da anedota para o estilo, do imprevisto cênico para o imprevisto da interpretação, descobre o encanto numeroso da leitura, que está mais no prisma do que no objeto". ${ }^{9}$ Esta transferência, ou transformação, como prefere Meyer, "do

7. João Alexandre Barbosa, em seu ensaio "A paixão crítica", que introduz o livro Textos críticos de Augusto Meyer, com seleção e organização do próprio Alexandre Barbosa, reproduz um trecho de Proust que dialoga perfeitamente com o ensaio de Meyer, "Do leitor", e em especial com o trecho reproduzido acima: "Não há, talvez, dias de nossa infância que tenhamos vivido tão plenamente quanto aqueles que acreditamos não ter vivido, aqueles que passamos com um livro favorito. Tudo o que parecia preenchê-los para os outros e que afastávamos como um obstáculo vulgar a um prazer divino: o jogo para o qual um amigo vinha procurar-nos na passagem mais interessante, a abelha ou o raio de sol incômodos que nos forçavam a levantar os olhos da página ou mudar de lugar, os lanches que nos tinham obrigado a trazer e que deixávamos ao nosso lado no banco, sem tocá-los, enquanto, sobre nossa cabeça, o sol enfraquecia no céu azul, o jantar para o qual era preciso voltar e durante o qual não pensávamos senão em retornar imediatamente para terminar o capítulo interrompido, tudo, que a leitura deveria impedir-nos de perceber qualquer outra coisa senão o importuno, gravava em nós, pelo contrário, uma lembrança de tal modo doce (tão mais preciosa em nosso julgamento presente do que o que líamos então com tanto amor) que, se nos acontece, ainda hoje folhear estes livros de outrora, não é senão como os únicos calendários que guardamos dos dias que se foram e com a esperança de ver refletidos em suas páginas lugares e recantos que não mais existem." (PROUST, apud BARBOSA. Paixão crítica, p. XXI-XXII).

8. MEYER. Textos críticos, p. 3.

9. MEYER. Textos críticos, p. 7. 
imprevisto cênico para o imprevisto da interpretação", é o primeiro passo para o surgimento do pensamento crítico no leitor, que a partir deste ponto se configura não mais como ator, mas espectador; atuante espectador, inclusive: "Se no leitor arrefecido esmorece o interesse pela fabulação, de outro lado observamos que aprende a cultivar o romance como documento psicológico e valor de arte". ${ }^{10}$ Essas palavras de Meyer nos mostram a mudança da postura do leitor: de leitor ingênuo para leitor-crítico, aquele que busca não se perder no cenário e na história contada pelo autor, mas sim interpretar a obra e ler nas entrelinhas. Leitor que se torna um escrutinador da obra, que a lê e relê, buscando sentidos subliminares, padrões formais na estrutura da obra e padrões psicológicos em seus personagens. Meyer é um caso clássico desse leitor ingênuo no qual se desenvolveu o senso crítico, mudando assim sua forma de recepcionar a obra.

Segundo Leyla Perrone-Moisés, a partir do final do século XIX, os escritores passaram a adotar uma postura autocrítica, criando uma literatura que refletia sobre a própria literatura. Essa postura adotada pelos escritores acabou desencadeando, em um segundo momento, uma reação por parte da crítica propriamente dita:

Ao mesmo tempo que a obra de criação assumia um caráter cada vez mais crítico, certos críticos começaram a revelar uma ambição crescente de autonomia, com relação às obras criticadas. Abandonando pouco a pouco a posição modesta de leitores e de guias de leitores, esses críticos passaram a aparecer como escritores cuja obra concorria, em termos de invenção, com a obra pretensamente analisada. Assistimos então ao aparecimento de um novo tipo de discurso literário, aflorando no lugar anteriormente ocupado pelo discurso crítico: um discurso crítico-inventivo no qual se fundem as características do discurso crítico e do discurso poético, até esse momento consideradas como inconciliáveis... ${ }^{11}$

\section{O conto-ensaio (a forma secreta)}

Augusto Meyer, em 1965, publica seu último livro de crítica literária, A forma secreta. Nessa obra o texto crítico, de viés literário, de Meyer atinge sua

10. MEYER. Textos críticos, p. 8.

11. PERRONE-MOISÉS. Texto, crítica, escritura, p. XII. [Grifo nosso.] 
forma mais elaborada, a de crítica-ensaio e crítica-conto. Na maioria dos textos que compõem o livro há uma quase total eliminação dos limites institucionalmente instaurados entre literatura e crítica. A literariedade está presente em todos os textos do livro, em equilíbrio com a análise teórica e interpretativa de obras e autores. Fausto Cunha, na introdução de $A$ forma secreta, diz o seguinte acerca desse equilibrio: "O raciocínio sutil e a beleza do tratamento literário enriquecem o que há de aprofundamento humano em suas meditações estéticas”. ${ }^{12}$

"Nova Odisséia" é o primeiro ensaio do livro. ${ }^{13}$ Neste texto Meyer resgata a figura de Ulisses; mas um Ulisses aposentado e entediado com sua vida monótona em terra firme:

E ali estava o engenhoso Ulisses, depois de tantas andanças na sua ilha, a bocejar a alma, enfarado de felicidade e repouso merecido. Tão escancarado era o bocejo de fartura, que parecia engolir, não só a ilhota das cabras, Ítaca, mas todo o reino das ilhas, Cefalônia, Leucádia e o mar brumoso ao longe. ${ }^{14}$

Augusto Meyer faz uso de construções literárias como "a bocejar a alma", "enfarado de felicidade" e "tão escancarado era o bocejo de fartura", para descrever seu Ulisses. Na verdade o mesmo Ulisses de Homero, porém agora mais consciente de seu destino, pelo menos assim o imagina Meyer:

Sentia musgo nas juntas e um gosto de mofo na boca. Sufocava nas sendas e veredas do seu reino, com inveja dos cabritos [...]. Pensar que ele, o tíbio Ulisses, com fama de aventuroso, ordenara que o amarrassem

12. CUNHA, apud MEYER. A forma secreta, (orelha).

13. O livro é composto por três partes: a primeira, intitulada de "Friso", possui oito ensaios, em que o hibridismo com o gênero conto e a imaginação do crítico se apresentam de forma marcante. Na segunda parte, intitulada de "O aprendiz grisalho", Meyer mantém o hibridismo entre os gêneros, mas se preocupa mais - na maioria dos textos (trinta e dois) - com a análise teórica e interpretativa, sem, contudo, abrir mão do texto escritural. A terceira parte, intitulada "Cartas abertas", é composta por doze textos em que o crítico utiliza a informalidade da correspondência para analisar obras ("Carta aberta sobre Cobra Norato"), autores ("O fenômeno Quintana") e temas variados, ligados à filosofia, à tradução, etc ("Carta dialética", "Bilhete dos cataventos").

14. MEYER. A forma secreta, p. 11. 
ao mastro, para não ceder ao apelo das sereias! Pois, que dizia a voz das sereias? Só agora, no mais profundo recolhimento noturno, quando a insônia do mar quebrava na praia, compreendia a sábia mensagem do seu canto. A verdadeira sabedoria - cantavam as sereias - era alimentar o espírito de inquietação, não perder o dom divino do anseio insatisfeito que não pára nunca e põe todo o amor na procura do amor. Entregar-se à ilusão da posse e da vitória, eis a cegueira irremediável, que transforma o herói numa sombra de si mesmo... Indigno do seu alto destino. Tapara os ouvidos à sedução da sabedoria. ${ }^{15}$

Augusto Meyer vislumbra um Ulisses envelhecido, morando em Ítaca, ilha em que "a insônia do mar quebrava na praia". Para o crítico, "a verdadeira sabedoria - cantavam as sereias - era alimentar o espírito de inquietação" e jamais "perder o dom divino do anseio insatisfeito que não pára nunca e põe todo amor na procura do amor". Meyer faz uso da prosa literária para expor sua visão e sua interpretação da obra de Homero, ou, mais precisamente, do personagem Ulisses. Para ele, Ulisses não cumpriu seu destino, pois "entregou-se à ilusão da posse e da vitória, eis a cegueira irremediável, que transforma o herói numa sombra de si mesmo". Ulisses não deveria ter tampado os ouvidos ao canto das sereias, não deveria ter tampado os ouvidos à sabedoria. O Ulisses que Augusto Meyer admira não é o de Homero, na Odisséia, mas sim aquele outro, que aparece no canto XXVI da Divina Comédia de Dante e que narra, em versos, sua última viagem, na qual perde a vida ao lado de seus companheiros.

No inferno, uma língua de fogo relatou a Dante essa aventura suprema: era a própria voz de Ulisses. E por mais que o poeta faça o herói soçobrar numa espécie de Maelstrom, como quem adverte os audaciosos e mostra o inevitável castigo da temeridade, o que no singular episódio logo impressiona é o tom prometeano. ${ }^{16}$

O ensaio, em seu desenvolvimento, ganha um tom heróico que busca se ajustar ao seu personagem e ao viés épico das obras que direta ou indiretamente lhe serviram de base:

15. MEYER. A forma secreta, p. 11.

16. MEYER. A forma secreta, p. 12. 
Desprezar os horizontes humanos do mundo conhecido, aproando para as solidões do Atlântico, era pronunciar a história do futuro, com a mesma audácia dos exploradores que no século XV descobriram os mares nunca de antes navegados, novos continentes sob o signo de estranhas constelações. ${ }^{17}$

O crítico, propositalmente, imprime um tom grandioso a seu discurso, em que Ulisses é alçado ao posto de precursor dos navegadores: "O cantor dessa grande empresa - dar ao mundo novos mundos - não chegou a ver no inquieto Ulisses o precursor dos navegadores celebrados no seu canto épico" ${ }^{18}$

O ensaio termina com a mesma dinâmica dos primeiros parágrafos, abrindo não apenas o texto-base a interpretações várias (ou textos-base, como é o caso), mas a si mesmo, texto crítico; pois se a "história não tem fim", o texto crítico, que é a história que se conta sobre a história - principalmente tratando-se de um conto-ensaio - também não:

É assim que a gesta recomeça e a história não tem fim. Inacabada ficará sempre qualquer Odisséia, enquanto houver a fecunda inquietação criadora [...] se o herói aceitasse a delícia das coisas imperfeitas, deixaria de reagir contra as fatalidades das limitações, que é o seu tormento. Não há regresso para Ulisses, há só partida. É a lição que não soube descobrir no canto das sereias senão muito mais tarde, para morrer navegando: Navigare necesse vivere non necesse. ${ }^{19}$

Há outro ensaio em A forma secreta, intitulado "Um certo Elpenor", que se configura como uma "complementação" de "Nova Odisséia", no qual Meyer "cria" uma história em que um personagem secundário da Odisséia, um certo Elpenor, acaba por cumprir o destino renegado pelo herói de Homero, Ulisses, segundo a concepção do crítico gaúcho. Vemos nesse ensaio características ainda mais acentuadas do conto-ensaio borgiano. Meyer inicia o ensaio assumindo a posição de um contador de histórias, mas um contador de histórias que faz uso da imaginação, caso contrário não seria necessário pedir ajuda às musas, que são entidades mitológicas capazes de inspirar a criação artística: "Eu contarei, se as

17. MEYER, A forma secreta, p. 12.

18. MEYER. A forma secreta, p. 13.

19. MEYER. A forma secreta, p. 13. 
musas me ajudarem, a verdadeira história de Elpenor. É mais importante, no seu conteúdo vertiginoso, que a guerra de Tróia e o regresso de Ulisses [...]” ${ }^{20}$ E continua, agora sim, dando plena vazão à literariedade de seu texto crítico:

Nem tudo cabe numa rapsódia, e os aedos vão deixando cair o que não acerta muito bem o passo com o ritmo do seu canto. Além do mais, todos sabemos, pelo exemplo da história, essa teia de Penélope, como é difícil desenlear o embrulho da meada, ao menos por descuido, e recolher na ponta dos dedos um humilde fiapo de verdade. ${ }^{21}$

Elpenor aparece brevemente no épico poema de Homero. Segundo Meyer, "Elpenor só aparece, portanto, na dourada pauta do poema, para desaparecer". 22 infortunado guerreiro, após abusar do vinho, adormece no terraço do templo de Circe e, durante o sono, se vira, cai e morre, reaparecendo, também brevemente, como uma sombra no Hades. Contudo, para Augusto Meyer o personagem possui um significado e uma importância bem maiores do que aquela dada pelo "lacônico relato de Ulisses", 23 e se propõe a contar sua verdadeira história. Segundo o crítico gaúcho, Elpenor "sofria do mal de muito imaginar [...]" ${ }^{24}$ O guerreiro não podia deixar de ver, em tudo, horríveis evidências. Em suas viagens ao lado de Ulisses, "[...] nas andanças por longes terras e mares, apenas via cobiça, vingança, embuste, carnagem, desvario [...]". 25 O crítico descreve, usando sua imaginação, o desejo contido de Elpenor de abandonar essa "dolorosa" vida:

Quantas vezes, ao marulho da vaga numa praia distante, imaginando na bruma o azulado perfil de uma ilha sem nome, onde a graça da manhã não conhece o declínio, o cismarento Elpenor desejou adormecer para sempre ao amargo embalo das ondas, e cabeceava exausto ao ritmo do seu remo $[\ldots]^{26}$

20. MEYER. A forma secreta, p. 14.

21. MEYER. A forma secreta, p. 14 .

22. MEYER. A forma secreta, p. 14.

23. MEYER. A forma secreta, p. 14.

24. MEYER. A forma secreta, p. 15.

25. MEYER. A forma secreta, p. 15.

26. MEYER. A forma secreta, p. 15. 
O trecho acima e o restante do texto é uma sequência inventada da história desse secundário personagem da Odisséia. Meyer nos conta que, enquanto se encontrava deitado, adormecido, no terraço de Circe, Elpenor escutava vozes que lhe diziam que os deuses o amavam e o chamavam para junto deles. O crítico compara essas vozes ao canto das sereias, à tentação da beleza. Antes de narrar o desfecho de seu Elpenor, Meyer escreve: "E assim chegamos ao momento crucial de nossa história". 27 É interessante notar que Meyer diz claramente "nossa história", se apropriando do personagem de Homero e criando para ele um fim mais digno. O Elpenor de Meyer também morre no final, mas sua morte é a opção de um homem revoltado com as injustiças do mundo e com a pusilanimidade dos seres humanos e dos semideuses:

Elpenor está deitado lá no alto do palácio de Circe, cheio de nojo e insônia. Bebeu sem quebra de água o espesso vinho tinto, para esquecer, mas não conseguiu dormir, e sob as pálpebras cerradas, enxameia um formigamento de visões: a peste no acampamento; as intrigas políticas desabrochando em aladas palavras, a rivalidade e as intermináveis recriminações e desavenças entre os maiorais; o rancoroso Aquiles com seu ridículo orgulho de galo de rinha ofendido nos seus brios; a rapacidade e a manha de Agamenon, general finório; Térsites, corcovado e hirsuto, babando injúrias, de envolta com puras verdades, e risos grosseiros; a carnagem vã, a rapina, as bravatas, o cadáver do nobre Heitor arrastado como um trapo, e a brutal hecatombe; o incêndio, o saque, o comércio de escravos, a partilha vil dos despojos [...]. ${ }^{28}$

Augusto Meyer nos narra a impressão que Elpenor tem dos seus companheiros e da empreitada em que está envolvido de uma maneira quase poética, preocupando-se com a escolha de palavras e expressões que transmitam a sua (de Elpenor) não menos poética visão do mundo e da vida, em contraposição à realidade em que está envolvido. O Elpenor de Meyer também está deitado no terraço de Circe e também bebeu vinho: "Bebeu sem quebra de água o espesso vinho"; porém, ao contrário do Elpenor de Homero, o de Meyer não consegue dormir, "e sob as pesadas pálpebras cerradas, enxameia um formigamento de

27. MEYER. A forma secreta, p. 15.

28. MEYER. A forma secreta, p. 15. 
visões"; "as intrigas políticas se desabrochando em aladas palavras [...]". E o crítico não faz a mínima economia de nosso léxico para descrever seus companheiros e seus atos "vis": Agamenon se destaca pela sua "rapacidade" e é um general "finório"; Térsites é "corcovado" e "hirsuto", e o cadáver do nobre Heitor sofreu a "carnagem vã", a "rapina" e as "bravatas" de seus companheiros, e tudo culmina em uma terrível "hecatombe".

O jovem guerreiro, do ponto de vista de Meyer, não suportou a visão de tanta infâmia e atrocidade, e então percebeu que não havia mais como regressar. Notou que tinha chegado ao fim do caminho, ou pelo menos do seu caminho nesse mundo:

Dia claro na primeira viração, recomeçou a ouvir a mesma carícia de VOZ interior, a murmurar com estranha doçura - Elpenor! Elpenor! Os deuses te amam, os deuses te chamam Elpenor... No mesmo instante, encheu-se a praia, lá embaixo, com a gritaria de Ulisses e Euríloco, a convocar os retardatários. Elpenor sorriu para o sol, caminhou serenamente ao encontro do seu destino...

O Elpenor de Meyer, ao contrário do Ulisses de Homero, não foge ao seu destino. Escuta o chamado de suas sereias e cumpre sua sina. A análise a que o crítico submete o texto de Homero é pontual, como não poderia deixar de ser, levando em consideração o espaço de menos de três páginas completas. Meyer se debruça sobre um ponto específico, qual seja, o personagem Ulisses e a fuga de seu próprio destino; e para isso usa o coadjuvante personagem Elpenor como contraponto. Contudo, a forma literária utilizada por Meyer, se não nos possibilita uma visão abrangente e aprofundada da obra de Homero, nos instiga à leitura ou releitura da mesma, mas agora sob uma nova ótica. Meyer lança uma mirada filosófica sobre o personagem Ulisses, nos colocando - leitores e simples mortais, representados por Elpenor - em uma posição superior à do próprio Ulisses, ou pelo menos na condição de estar nessa posição, bastando para isso não fugirmos ao nosso destino. Mas que destino seria esse? Qual o destino de Elpenor? Qual o nosso? Meyer não nos diz e nem é esse o objetivo de seu curto ensaio. Essa pequena peça crítica e literária nos faz mais perguntas do que nos dá respostas. Segundo Gerard Genette, uma das funções do texto crítico-poético (ou como ele

29. MEYER. A forma secreta, p. 16. 
mesmo chama, crítica moderna): "[...] é produzir sentido com a obra dos outros, mas também fazer a sua obra com esse sentido".

Fábio Lucas chama a atenção para esse lado poético e de coexistência entre obra crítica e obra criticada, presentes no ensaio de Augusto Meyer, inclusive citando os três últimos textos analisados por nós:

Mais de uma vez assinalamos o lado poético do ensaio de Augusto Meyer. O leitor poderá ter uma noção exata de sua capacidade de coexistir com a obra analisada, de desenvolver uma empatia identificadora com o texto alheio, uma espécie de co-naturalidade discursiva, ao ler "Evocação de Virgínia Woolf", trata-se de puro lirismo, uma espécie de impressionismo onírico. O mesmo teor se repete em "Nova Odisséia", "Um certo Elpenor" e "A viagem de Virgílio", todos provenientes da obra A forma secreta (1965), da qual Fausto Cunha disse ser a culminância das qualidades de ensaísta e prosador de Augusto Meyer. ${ }^{32}$

Estamos nos referindo, já há algumas páginas, aos ensaios de Augusto Meyer como "conto-ensaio". Não há, na obra de Augusto Meyer e nem nos principais estudos escritos sobre seu trabalho crítico, nenhuma evidência clara que nos

30. GENETTE. Estruturalismo e crítica literária, p. 370.

31. O conto-ensaio que fecha essa espécie de trilogia clássica, em que Meyer aborda de forma enviesada as obras de Homero e Virgílio, e de forma indireta Dante e Camões, se encerra com "A viagem de Virgílio". Optamos por não nos imiscuir na análise deste ensaio e passarmos para os da segunda parte, para que dessa forma possamos fazer uma amostragem mais equilibrada dos ensaios contidos no livro. Apenas a título de nota, "A viagem de Virgílio" trata de Virgílio e sua Eneida, mas aborda de forma complementar - realizando um entrelaçamento entre as duas obras -, A morte de Virgílio, de Hermann Broch, a quem o ensaio é sugestivamente dedicado. Abaixo reproduzimos um pequeno trecho do ensaio em que a literariedade de Meyer se deixa entrever: "Tosse, tosse, cospe o teu resto de vida, o teu verso truncado, o teu último alento, Virgílio... Que mais queres? Sem dúvida alguma, a ocasião é boa para pensar um pouco nas palavras de Lucrécio; transformadas em realidade, já não soam a poesia, isto é, um misto de ser e parecer, mas pesam com toda a evidência de pedras caindo num poço." (MEYER. A forma secreta, p. 18).

32. LUCAS. Caminhos da crítica de Augusto Meyer, p. 26. 
respalde no afirmar alguma influência marcante de Jorge Luiz Borges ${ }^{33}$ em sua produção crítica; mas, sem dúvida, não há como deixar de notar algumas semelhanças na obra de ambos, principalmente se tomarmos como base o Augusto Meyer de A forma secreta. Assim como o escritor argentino, Augusto Meyer era dotado de uma erudição que o destacava entre seus pares. Seus ensaios estão repletos de citações que remetem à literatura clássica ou a compêndios de filosofia, teoria literária e linguística há muito esquecidos pelos estudiosos ou mesmo desconhecidos por muitos. Uma diferença que, contudo, devemos realçar antes de começarmos a destacar as semelhanças, é que Borges era um escritor-crítico, que usava livremente a ficção para tecer seus comentários acerca de algumas obras. Já Meyer era um crítico-escritor, que usava a forma literária para expor seus comentários críticos. Segundo suas próprias palavras, contidas no ensaio "Teoria da literatura", que faz parte do livro Preto \& branco:

Veremos assim que, quanto mais se desenvolve a pesquisa formal da obra literária mais se impõe a necessidade de coordenar todos os resultados numa unidade expressiva peculiar, que logo nos reconduz ao pólo oposto, ou seja, à crítica do conteúdo, da essência, do espírito que anima essa obra. ${ }^{34}$

A obra de Borges é ficcional em sua essência, o que permite um descompromisso com o mundo real. Já Augusto Meyer é um crítico que, ao fazer uso da escritura, cria um texto que é literário em sua forma ("numa unidade expressiva peculiar"), mas crítico em sua essência.

Contudo, um ponto em comum entre os dois autores e que é fundamental para a aproximação das duas obras, é a busca pela superação de um padrão mimético-realista. Essa busca é mais do que evidente em Borges, mas

33. Tânia Franco Carvalhal, em O crítico à sombra da estante, dedica apenas um parágrafo à aproximação entre as obras dos dois autores: "A afinidade de Meyer com o escritor argentino é muito grande. Em A forma secreta a presença de Borges transparece em epígrafe e na coincidência de preocupações. No confronto da última obra do crítico rio-grandense com Discusión (Buenos Aires, EMECE, 1964, 3. Ed.) verifica-se que também Borges reviveu Homero, analisou o problema da causalidade em "A Arte Narrativa e a Magia', e questionou aspectos teórico-literários de traduções." (CARVALHAL. O crítico à sombra da estante, p. 113).

34. MEYER. Preto \& branco, p. 227. 
também pode ser encontrada em Meyer. Nos ensaios contidos em A forma secreta, percebemos a presença de "espaços literários" que buscam subverter os estreitos limites formais de uma crítica "tradicional".

Há, porém, uma diferença marcante entre os textos dos dois autores: o compromisso com a realidade. No escritor argentino esse compromisso não existe, nem mesmo quando escreve seus contos-ensaios de fundo crítico. Borges é famoso por "brincar" com seu leitor, por procurar confundi-lo com suas citações. Nem sempre sabemos ao certo quais das obras citadas realmente existem e quais são produtos da imaginação de Borges. Em Meyer esse jogo de enganação com seu leitor não é permitido. O que deve prevalecer em seus contos-ensaios é o teor crítico, e para isso o real não pode ser subvertido acima de um determinado limite. O crítico se dá ao direito, por exemplo, de criar histórias paralelas para se aproximar de uma determinada obra - como fez em "Um certo Elpenor" -, mas de maneira alguma se permite inventar referências bibliográficas (como Borges) que lhe deem suporte em suas análises. O que seria um contra-senso em relação a um dos princípios básicos da crítica: o "pacto" de confiança entre crítico e leitor. O primeiro não tem o direito, devido à relação que implicitamente se estabelece, de "enganar" seu leitor.

Em A forma secreta, cujo título é claramente inspirado em uma frase de Borges ("El pensamiento más fugaz obedece a un dibujo invisible y puede coronar, o inaugurar, una forma secreta". ${ }^{35}$ ), há um ensaio dedicado ao escritor argentino, no qual Meyer analisa a presença de Deus como personagem borgiano, inclusive servindo de fecho a dois ensaios de O Aleph: "Os teólogos" e "História do guerreiro e da cativa". Augusto Meyer não poupa elogios a Borges, mesmo quando lhe dá um leve puxão de orelha, ao dizer que o autor abusa do direito de ser Deus "[...] e com uma espécie de ascetismo da acrobacia estética, o autor não relaxa os músculos, não se concede o mais leve cochilo homérico, e quando muito aceita um mínimo de ingenuidade épica”. ${ }^{36}$ Meyer inicia seu ensaio de uma maneira bem borgiana, com uma série de citações eruditas, muitas delas retiradas dos ensaios de Borges citados acima (outras citações e autores são inseridos pelo próprio Meyer, como, por exemplo, Heráclito e Clémence Ramnoux): "Sous des formules rédutibles à quelque structure grammaticale simple les enigmes répètent le principe

35. BORGES, apud MEYER. A forma secreta, p. 111.

36. MEYER. A forma secreta, p. 111. 
de l'unité des contraires (v. Héraclite ou l'homme entre les choses et les mots, belles lettres, 1959), ${ }^{37}$ Em um determinado ponto do texto, Meyer fala da "lucidez poética" e da "intuição criadora" do autor argentino:

Tudo isso envolve necessariamente, além de uma arte soberana e quase escandalosa no governo da lucidez poética, sempre a cavaleiro da intuição criadora, certa franja de paralogia metafísica, impregnada de humorismo transcendente, aquele capitoso humour borgiano que vai espicaçando o nosso espanto com o arabesco renovado e aberto de uma fantasia desatada em imprevisto e agilidade. ${ }^{38}$

Poderíamos também, buscando usar o mesmo tom adotado por Meyer, dizer que o crítico gaúcho sabia fazer uso de uma arte soberana, em que a lucidez da análise literária e o julgamento crítico se encontravam, quase sempre, a cavaleiro da forma poética. Como no trecho a seguir:

Há em Borges, a um só tempo, um zaori e um diabo rengo, um olho clarividente, a par de um olho vesgo e turvo, que mistura as coisas por gosto e magia, para que pareçam mais ameaçadas, mais imprecisas e mais poéticas. Da imprecisão, uma imprecisão lúcida e precisa, ele soube fazer um acerado instrumento de sugestões poéticas [...]. Já dizia Nietzsche, com implacável ironia, que era essa a função dos poetas: toldar as águas, para que pareçam mais profundas.

Percebemos na obra crítica de Augusto Meyer, mas principalmente em seu último livro, um "prazer" que pouco conseguiu disfarçar: um prazer de leitor, um prazer de crítico e um prazer de esteta da língua, ao usar a forma "poética" para analisar obras, autores e conceitos literários. Segundo Tânia Franco Carvalhal:

Em A chave e a máscara e A forma secreta há dois traços singulares perceptíveis ao leitor atento, que distinguem essas duas obras da produção anterior. Julgo ser adequado denominá-los de prazer e melancolia da crítica. O primeiro é reflexo do gozo continuado que Meyer encontrava

37. MEYER. A forma secreta, p. 110.

38. MEYER. A forma secreta, p. 111.

39. MEYER. A forma secreta, p. 111. 
no contato com os textos literários. "Ler um livro" - dizia-nos já em $\grave{A}$ sombra da estante - "é desinteressar-se a gente deste mundo comum e objetivo para viver noutro mundo". Um gozo e um hábito cada vez mais esquecidos. Recentemente Roland Barthes analisou com muita pertinência esta questão em obra de título sugestivo: Le plaisir du texte. ${ }^{40}$

Acreditamos que uma das melhores definições para o texto crítico de Augusto Meyer é aquela que ele mesmo deu a outro crítico, de uma geração anterior à sua. O crítico gaúcho diz o seguinte sobre a obra ensaística de João Ribeiro e que poderia adequar-se muito bem ao seu próprio caso: "É a superação do ensaísmo pela poesia do ensaio". " Um ensaio que supera os próprios limites do ensaio através do uso renovado da linguagem e dos conceitos: o uso de uma linguagem "poética" (escritural, literária) para expor conceitos de teoria literária e exteriorizar julgamentos de valor. A obra crítica de Augusto Meyer nos deixa bem claro que o leitor e a leitura são a origem e o fim último da crítica. ${ }^{42}$ E uma das maneiras mais eficientes do crítico atingir o leitor é, sem dúvida, através do uso da literatura para falar da própria literatura.

\section{Augusto Meyer: the poetic speech on literary criticism}

Abstract: This essay aims to demonstrate the presence of a speech "poetic" in the critical work of Augusto Meyer. To this end we conducted a survey of his literary journey and we dedicated to the analysis of excerpts from some of their tests of maturity.

Keywords: criticism; poetics; Augusto Meyer.

40. CARVAlhal. O crítico à sombra da estante, p. 114.

41. MEYER. A chave e a máscara, p. 205.

42. "Era mais uma vez assumir o leitor e a leitura como origem e fim da crítica. E mais uma, e última superação: a que vence a distância entre a linguagem da obra e sua configuração histórica."42 (BARBOSA. Augusto Meyer ensaísta, p. 17). 


$$
\text { Referências }
$$

BARBOSA, João Alexandre. Augusto Meyer ensaísta. Cult, São Paulo, n. 54, p. 16. Ano V, 2002.

BARBOSA, João Alexandre. Paixão Crítica. In: MEYER, Augusto. Textos Críticos: Coleção. Perspectiva pró-memória. Instituto Nacional do livro. Org. João Alexandre Barbosa. São Paulo: Editora Perspectva, 1986.

BARTHES, Roland. Crítica e verdade. São Paulo: Perspectiva, 1999.

BARTHES, Roland. O prazer do texto. São Paulo: Perspectiva, 2005.

BORGES, Jorge Luis. O aleph. São Paulo: Editora Globo, 1992.

CARVAlHAL, Tânia Franco. A evidência mascarada na poesia de Augusto Meyer. Porto Alegre: L \& PM Editores; Brasília: INL, 1984.

CARVAlHAL, Tânia Franco. O crítico à sombra da estante: levantamento e análise da obra de Augusto Meyer. Porto Alegre: Globo, 1976.

GENETTE, Gerard. Estruturalismo e crítica literária. In: COELHO, Eduardo Prado (Org). Estruturalismo - antologia de textos teóricos. Lisboa: Portugália, 1968. p. 367-392.

LUCAS, Fábio. Caminhos da crítica de Augusto Meyer. In: JUNQUEIRA, Ivan (Org.). Ciclo de conferências em homenagem ao centenário de nascimento do acadêmico Augusto Meyer. Rio de Janeiro: ABL, 2002.

MEYER, Augusto. Machado de Assis. Porto Alegre: Edição da Livraria do Globo, 1935.

MEYER, Augusto. A forma secreta. Rio de Janeiro: Francisco Alves, 1965.

MEYER, Augusto. A chave e a máscara. Rio de Janeiro: Edições O Cruzeiro, 1964.

MEYER, Augusto. À sombra da estante. São Paulo: José Olympio, 1947.

MEYER, Augusto. Coração verde. 2. ed. Porto Alegre: Globo, 1929.

MEYER, Augusto. Preto \& branco. Rio de Janeiro: INL, 1956.

MEYER, Augusto. Poesias. Rio de Janeiro: São José, 1957.

MEYER, Augusto. Textos críticos. Org. João Alexandre Barbosa. São Paulo: Editora Perspectiva, 1986.

MORAES, Carlos Dante de. Realidade e ficção. Rio de Janeiro: Cadernos de Cultura, 1952.

PERRONE-MOISÉS, Leyla. Escolher e/é julgar. In: Cadernos de Colóquio/Letras, n. 1, Lisboa, Fundação Calouste Gulbenkian, s/d.

PERRONE-MOISÉS, Leyla. Texto, crítica, escritura. São Paulo: Martins Fontes, 2005.

PORTELLA, Eduardo. Reencontrando Augusto Meyer. In: LUCAS, Fábio. Caminhos da crítica de Augusto Meyer. In: Ciclo de conferências em homenagem ao centenário de nascimento do acadêmico Augusto Meyer. Rio de Janeiro: ABL, 2002. 